\title{
Increased IGF mRNA in Human Skeletal Muscle after Creatine Supplementation
}

\author{
LOUISE DELDICQUE $^{1}$, MAGALI LOUIS ${ }^{1}$, DANIEL THEISEN ${ }^{1}$, HENRI NIELENS $^{1}$, MISCHAËL DEHOUX ${ }^{2}$, \\ JEAN-PAUL THISSEN $^{2}$, MICHAEL J. RENNIE ${ }^{3}$, and MARC FRANCAUX ${ }^{1}$ \\ ${ }^{1}$ Department of Physical Education and Rehabilitation, Faculty of Medicine, Catholic University of Louvain, Louvain-la- \\ Neuve, BELGIUM; ${ }^{2}$ Unit of Diabetology and Nutrition, Faculty of Medicine, Catholic University of Louvain, Brussels, \\ BELGIUM; and ${ }^{3}$ School of Biomedical Sciences, University of Nottingham Graduate Entry Medical School, Derby, \\ UNITED KINGDOM
}

\begin{abstract}
DELDICQUE, L., M. LOUIS, D. THEISEN, H. NIELENS, M. DEHOUX, J.-P. THISSEN, M. J. RENNIE, and M. FRANCAUX. Increased IGF mRNA in Human Skeletal Muscle after Creatine Supplementation. Med. Sci. Sports Exerc., Vol. 37, No. 5, pp. 731-736, 2005. Purpose: We hypothesized that creatine supplementation would facilitate muscle anabolism by increasing the expression of growth factors and the phosphorylation of anabolic signaling molecules; we therefore tested the responses of mRNA for IGF-I and IGF-II and the phosphorylation state of components of anabolic signaling pathways p70 ${ }^{\mathrm{s} 6 \mathrm{k}}$ and 4E-BP1 to a bout of high-intensity resistance exercise after $5 \mathrm{~d}$ of creatine supplementation. Methods: In a double-blind cross-over design, muscle biopsies were taken from the $\mathrm{m}$. vastus lateralis at rest and 3 and $24 \mathrm{~h}$ postexercise in subjects who had taken creatine or placebo for $5 \mathrm{~d}\left(21 \mathrm{~g} \cdot \mathrm{d}^{-1}\right)$. For the first $3 \mathrm{~h}$ postexercise, the subjects were fed with a drink containing maltodextrin $\left(0.3 \mathrm{~g} \cdot \mathrm{kg}^{-1}\right.$ body weight $\left.\cdot \mathrm{h}^{-1}\right)$ and protein $(0.08$ $\mathrm{g} \cdot \mathrm{kg}^{-1}$ body weight $\left.\cdot \mathrm{h}^{-1}\right)$. Results: After creatine supplementation, resting muscle expressed more mRNA for IGF-I $(+30 \%, P<0.05)$ and IGF-II $(+40 \%, P=0.054)$. Exercise caused an increase by $3 \mathrm{~h}$ postexercise in IGF-I $(+24 \%, P<0.05)$ and IGF-II $(+48 \%, P$ $<0.05)$ and by $24 \mathrm{~h}$ postexercise in IGF-I $(+29 \%, P<0.05)$, but this effect was not potentiated by creatine supplementation. The phosphorylation states of $\mathrm{p} 70^{\mathrm{s} 6 \mathrm{k}}$ and 4E-BP1 were not affected by creatine at rest; phosphorylation of both increased $(150-400 \%, P$ $<0.05)$ to similar levels under placebo and creatine conditions at $3 \mathrm{~h}$ postexercise plus feeding. However, the phosphorylation state of 4E-BP1 was higher in the creatine versus placebo condition at $24 \mathrm{~h}$ postexercise. Conclusion: The increase in lean body mass often reported after creatine supplementation could be mediated by signaling pathway(s) involving IGF and 4E-BP1. Key Words: RESISTANCE EXERCISE, PROTEIN SYNTHESIS, P70 ${ }^{\mathrm{S} 6 \mathrm{~K}}$, 4E-BP1, REAL-TIME RT-PCR
\end{abstract}

$\mathrm{O}$ ver the last $15 \mathrm{yr}$, the use of creatine as an ergogenic aid has increased markedly, especially among strength and power athletes. Surprisingly, creatine supplementation has been found not only to increase the short-term power output during high-intensity exercises but to result in significant increases in lean body, particularly muscle mass (3). There is evidence that this increase is mainly intracellular, suggesting that the cell dry mass is increased (8). Additionally, a number of workers have found increases in muscle fiber area $(26,27,29)$. Taken together,

\footnotetext{
Address for correspondence: Prof. Marc Francaux, Department of Physical Education and Rehabilitation, Place Pierre de Coubertin-1, B-1348 Louvain-la-Neuve, Belgium; E-mail: marc.francaux @edph.ucl.ac.be. Submitted for publication October 2004.

Accepted for publication December 2004.
}

0195-9131/05/3705-0731

MEDICINE \& SCIENCE IN SPORTS \& EXERCISE E $_{\circledast}$

Copyright (C) 2005 by the American College of Sports Medicine

DOI: $10.1249 / 01 . M S S .0000162690 .39830 .27$ these observations suggest that creatine could enhance muscle growth by stimulating protein synthesis.

In previous studies $(14,15)$ we set out to discover whether $5 \mathrm{~d}$ of oral creatine supplementation could potentiate protein synthesis in human muscle. We could not confirm this hypothesis either at rest in the postabsorptive or fed state, or at rest after an acute bout of resistance exercise. These results could be interpreted in several ways. First, it is possible that creatine has no anabolic effect on muscle, which would, however, not be in line with previous observations (see above). Second, creatine might have an effect but beyond the time frame of our previous experiments $(<3.5 \mathrm{~h})$. Third, the effect of creatine could be small and below the detection limits of our previously used methods.

Insulinlike growth factor I (IGF-I) is known to increase muscle protein synthesis and to stimulate satellite cell proliferation and differentiation in vitro (1). Recently, we showed that myogenic $\mathrm{C}_{2} \mathrm{C}_{12}$ cells incubated with creatine differentiated more rapidly than in control conditions; this 
observation was associated with an increase in IGF-I mRNA expression (16).

IGF-II, another member of the IGF family, is also produced by skeletal muscle and is involved in muscle differentiation and regeneration (12). IGF activate several cellular pathways regulating muscle atrophy and hypertrophy, including the PI3K-Akt/PKB-mTOR signaling pathway (24).

The PI3K-Akt/PKB-mTOR pathway is involved in the regulation of skeletal muscle fiber size and in the stimulation of translation initiation by activating mTOR and two of its downstream effectors: p70 ${ }^{\mathrm{s} 6 \mathrm{k}}$ and 4E-BP1 (eukaryotic initiation factor-4e binding protein-1) also called PHAS-I (phosphorylated heat- and acid-stable protein regulated by insulin). $\mathrm{p} 70^{\mathrm{s} 6 \mathrm{k}}$ and $4 \mathrm{E}-\mathrm{BP} 1$ are two key regulators of protein synthesis. $\mathrm{p} 70^{\mathrm{s} 6 \mathrm{k}}$ phosphorylates the ribosomal phosphoprotein S6 on the 40S subunit (20). S6 is involved in the translation of a class of mRNA called TOP mRNAs (due to their terminal region rich in oligopyrimidines). This class of mRNA encodes for components of the translational machinery and elongation factors (11). The phosphorylation state of $\mathrm{p} 70^{\mathrm{s} 6 \mathrm{k}}$ and consequently its activity are increased by amino acids, insulin, and exercise (23).

4E-BP1, a translational repressor (6), can bind to the initiation factor eIF4E to prevent the formation of the eIF4F scaffolding complex, which is necessary for efficient binding of the $40 \mathrm{~S}$ ribosomal subunit to mRNA. When 4E-BP1 is hyperphosphorylated, it dissociates from eIF4E allowing it to participate in translation initiation. In human skeletal muscle, 4E-BP1 is activated by branched chain amino acid infusion (13) and exercise (21).

Because we previously could not demonstrate an acute increase in protein synthesis after creatine ingestion $(14,15)$, we hypothesized that creatine has a measurable effect on downstream regulatory factors from the PI3K-Akt/PKBmTOR pathway and that it could act upstream, in a longer time frame, via the IGF. Therefore, the aim of the present study was to test the prediction that creatine supplementation alone would enhance IGF-I and IGF-II gene expression, and increase the phosphorylation state of $\mathrm{p} 70^{\mathrm{s} 6 \mathrm{k}}$ and $4 \mathrm{E}-$ BP1. Furthermore, we speculated that high-intensity resistance exercises would potentiate these effects.

\section{MATERIALS AND METHODS}

\section{Subjects and Study Design}

Six healthy young men (age $23 \pm 0.6 \mathrm{yr}$, body mass $77.1 \pm$ $5.1 \mathrm{~kg}$, height $186 \pm 1.0 \mathrm{~cm}$ ) who were physically active but not specifically trained for resistance exercises participated in this double-blind, cross-over study. All subjects were given an oral and written account of the study before signing an informed consent form. This study was approved by the ethics committee of the Université Catholique de Louvain, and all the procedures used were in accordance with the Declaration of Helsinki. The subjects were randomly divided into two groups: one group $(N=3)$ received $21 \mathrm{~g}$ of oral creatine monohydrate per day for $5 \mathrm{~d}$, whereas the second group $(N=3)$ received a placebo (maltodextrin $21 \mathrm{~g}$ ). After a washout period of 1 month, the treatments were crossed over.

\section{Protocol}

During an initial familiarization session $1 \mathrm{wk}$ before the main study, each subject completed a leg-press test with one leg to determine the one-repetition maximum (1-RM). The subjects were free to choose their preferred leg for exercise, but they were asked to use the same leg subsequently for both the creatine and placebo trials.

The day before and the day of the experiment, the subjects were asked not to participate in any sport activities and to maintain their usual diet. On the day of testing, subjects reported to the laboratory at 8.00 a.m. after an overnight fast, and a muscle biopsy was taken at rest from the vastus lateralis. Subsequently, subjects received a standardized meal (two croissants $(2 \times 60 \mathrm{~g})$ and one glass of orange juice $(200 \mathrm{~mL}))$, after which they began the exercise session. They first warmed up with three sets of 10 repetitions on the leg press. The subsequent exercise test consisted of 10 sets of 10 leg-press repetitions (every $5 \mathrm{~s}$ ) at $70 \%$ of each individual 1-RM. The sets were interspersed with 2-min rest periods, and the subjects received verbal encouragement throughout the exercise session. During the first hour postexercise, the subjects ingested a drink containing 0.3 $\mathrm{g} \cdot \mathrm{kg}^{-1}$ body weight $\cdot \mathrm{h}^{-1}$ maltodextrin (Nestlé; Caloreen, Brussels, Belgium) and $0.08 \mathrm{~g} \cdot \mathrm{kg}^{-1}$ body weight $\cdot \mathrm{h}^{-1}$ skimmed milk protein powder (Nutricia; Protifar Plus, Bornem, Belgium) dissolved in water. A second muscle biopsy was taken $3 \mathrm{~h}$ postexercise from the exercised leg (with the subjects in the fed state), and a third biopsy was taken the following day, $24 \mathrm{~h}$ postexercise, in the fasted state. All the biopsies were taken from the midportion of the vastus lateralis muscle with a 4-mm Bergström biopsy needle after local anesthesia with $1 \%$ lidocaine. Blood, macroscopically visible fat, and connective tissue were quickly removed, and the sample was immediately frozen in liquid nitrogen and stored at $-80^{\circ} \mathrm{C}$ for later analysis.

\section{RNA Extraction and Quantitative Real-Time PCR}

Total RNA was prepared from frozen tissue samples $(90$ mg) using TRIZOL ${ }_{\circledast}$ (Gibco Life Technologies, Paisley, UK). RNA was quantified by spectrophotometry $(\lambda=260$ $\mathrm{nm})$, and its concentration adjusted to $1 \mu \mathrm{g} \cdot \mu \mathrm{L}^{-1}$ using RNase-free water. Reverse transcription (RT) was performed using the GeneAmp PCR system 2400 (Applied Biosystems, Foster City, CA) with $1 \mu \mathrm{g}$ of total RNA in a reaction volume of $20 \mu \mathrm{l}$, containing $7.5 \mu \mathrm{M}$ random hexamers, RT buffer 1X, $9 \mathrm{mM}$ dithiothreitol, $220 \mu \mathrm{M}$ of each

TABLE 1. Sequences of primers used for mRNA quantification by real-time RT-PCR.

\begin{tabular}{llc}
\hline Primer Name & \multicolumn{1}{c}{ Sequence $\left(\mathbf{5}^{\prime}\right.$ to $\left.\mathbf{3}^{\prime}\right)$} & Accession No. \\
\hline$\beta-2-\mu$ globulin Fw & gga ggc tat cca gcg tac tcc & NM_004048 \\
$\beta-2-\mu$ globulin Rv & cgg atg gat gaa acc cag ac & \\
IGF-I Fw & atc agc agt ctt cca acc caa & NM_000618 \\
IGF-I Rv & cag cgc cag gta gaa gag atg & \\
IGF-II Fw & agc ttg ttg aca cgc ttc agt & NM_000612 \\
IGF-II Rv & tgc cct ctc tca act ctt tga & \\
\hline
\end{tabular}


deoxyribonucleotide triphosphate (dNTP), $20 \mathrm{U}$ ribonuclease inhibitor (Applied Biosystems), and $50 \mathrm{U}$ of reverse transcriptase (Superscript ${ }_{\circledast}$, Gibco, BRL). The final RT product was adjusted to $40 \mu \mathrm{L}$ using RNase free water. Real-time RT-PCR (reverse transcription-polymerase chain reaction) primers were designed (Table 1, Primer Express Software, Applied Biosystems) for human IGF-I, IGF-II, and $\beta$-2-microglobulin. The latter was used as the "house keeping" gene, because preliminary experiments as well as a previous study (19) had revealed that it was not affected by either exercise or creatine supplementation. In the current study, the intrasubject coefficient of variation $(\mathrm{CV})$ of the threshold cycle $(\mathrm{Ct})$ values varied between 0.9 and $3.9 \%$. Sybr Green ${ }_{\circledast}$ real-time RT-PCR analyses were carried out on the GeneAmp 5700 (Applied Biosystems) using the following cycle conditions: $10 \mathrm{~min}$ at $95^{\circ} \mathrm{C}$, followed by 40 cycles of $1 \mathrm{~min}$ at $60^{\circ} \mathrm{C}$ and $15 \mathrm{~s}$ at $95^{\circ} \mathrm{C}$. For each gene, real-time RT-PCR was conducted in duplicate with a $25-\mu \mathrm{L}$ reaction volume of $5 \mathrm{ng}$ of cDNA, 2.5- $\mu \mathrm{L}$ Sybr Green ${ }_{\circledast}$ buffer, $250 \mu \mathrm{M}$ dNTP, $3 \mathrm{mM} \mathrm{MgCl} 2,400 \mathrm{nM}$ of each primer, and $0.625 \mathrm{U}$ AmpliTaq Gold ${ }_{\circledast}$ DNA Polymerase (Applied Biosystems). To ensure the quality of the measurements, each plate included, for each gene, a negative control (sample replaced by RNase free water) and a positive control consisting of an aliquot from a mixed pool of cDNA of positive samples. Ct from a positive sample was used to calculate the interassay CV. For each gene, the CV was calculated as standard deviation/mean of the $2 \mathrm{Ct}$ determined on five different plates and with different mixes. Typically, the $\mathrm{CV}$ obtained was $\sim 5 \%$. The mRNA results are presented as $\Delta \mathrm{Ct}$ : $\mathrm{Ct}_{\text {gene of interest }}-\mathrm{Ct}_{\text {house keeping gene }}$.

\section{Western Immunoblotting Techniques}

$\mathbf{p 7 0} \mathbf{S 6}^{\mathbf{6 k}}$. About $20 \mathrm{mg}$ of frozen muscle were ground in a mortar and homogenized in ice-cold buffer $(20 \mathrm{mM}$ Tris, $\mathrm{pH}$ 7.0, $0.27 \mathrm{M}$ sucrose, 5 mM EGTA, 1 mM EDTA, 1\% Triton $\mathrm{X}-100,1 \mathrm{mM}$ sodium orthovanadate, $50 \mathrm{mM}$ sodium $\beta$-glycerophosphate, $5 \mathrm{mM}$ sodium pyrophosphate, $50 \mathrm{mM}$ sodium fluoride, $1 \mathrm{mM}$ 1,4-dithiothreitol (DTT), and a protease inhibitor cocktail containing $1 \mathrm{mM}$ EDTA (Roche Applied Science, Mannheim, Germany)) (25). The homogenate was immediately centrifuged at $10,000 \times g$ for $10 \mathrm{~min}$ at $4^{\circ} \mathrm{C}$. The supernatants were stored in liquid nitrogen. Protein concentration was determined using the DC protein assay kit (Bio-Rad Laboratories, Hercules, CA).

Cell lysates (40 $\mu \mathrm{g}$ of protein) were combined with Laemmli sample buffer and separated by SDS-PAGE (sodium dodecylsulfate polyacrylamide gel electrophoresis) using an $8 \%$ gel. After electrophoretic separation at $40 \mathrm{~mA}$, the proteins were transferred at $80 \mathrm{~V}$ for $90 \mathrm{~min}$ to a PVDF membrane (Amersham Biosciences, Uppsala, Sweden) for Western analysis. All membranes were incubated for the same time and in the same conditions. Membranes were incubated for $2 \mathrm{~h}$ in a $5 \%$ Blotto solution (5\% powdered milk in Tris buffer saline with $0.01 \%$ Tween-20, TBST) containing $50 \mathrm{mM} \mathrm{NaF}$ to inhibit phosphatases. The blocking solution was then poured off. The phospho-specific p70 ${ }^{\mathrm{s} 6 \mathrm{k}}$ antibody (1:1000) [(Thr389),
Santa Cruz Biotechnology, Santa Cruz, CA] was added and incubated overnight at $4^{\circ} \mathrm{C}$ in Blotto containing $50 \mathrm{mM} \mathrm{NaF}$. Membranes were washed $(3 \times 10 \mathrm{~min})$ in TBST and then incubated for $1 \mathrm{~h}$ at room temperature in secondary antibody conjugated to horseradish peroxidase $(1: 10,000)$ (Calbiochem, San Diego, CA) in a 5\% Blotto solution. After an additional three washes in TBST, chemiluminescent detection was carried out using an ECL Western blotting kit (Amersham Biosciences). As a loading control, membranes were then stripped and reprobed with an anti-p70 ${ }^{\mathrm{s} 6 \mathrm{k}}$ (1:1000) (Santa Cruz Biotechnology) that recognizes both phosphorylated and nonphosphorylated forms. Total $\mathrm{p} 70^{\mathrm{s} 6 \mathrm{k}}$ was found to be unchanged by creatine and exercise. The films were scanned on an ImageScanner using the Labscan Software and quantified with the Image Master 1D Image Analysis Software (Amersham Biosciences).

4E-BP1. Muscle samples were treated as described by $\mathrm{Xu}$ et al. (30). About $20 \mathrm{mg}$ of muscle were homogenized in ice-cold buffer $(50 \mathrm{mM}$ sodium $\beta$-glycerophosphate, $\mathrm{pH}$ 7.3, $100 \mathrm{mM}$ sodium fluoride, $5 \mathrm{mM}$ EDTA, $2 \mathrm{mM}$ EGTA, $0.1 \mathrm{mM}$ sodium orthovanadate, $1 \mathrm{mM}$ benzamidine, 10 $\mu \mathrm{g} \cdot \mathrm{mL}^{-1}$ leupeptin, and $0.2 \mathrm{mM}$ phenylmethylsulfonyl fluoride). The homogenate was centrifuged at $10,000 \times g$ for $20 \mathrm{~min}$ at $4{ }^{\circ} \mathrm{C}$. The supernatant was heated at $100^{\circ} \mathrm{C}$ for 10 min and was then centrifuged at $10,000 \times g$ for $30 \mathrm{~min}$ at $4{ }^{\circ} \mathrm{C}$. The supernatants were stored in liquid nitrogen for further analysis. The proteins were combined with Laemmli sample buffer and separated on a $15 \%$ gel by SDS-PAGE. Proteins were transferred to a PVDF membrane. After incubation in a 5\% Blotto solution, PHAS-I antibody (1:1000) (Calbiochem) was added and incubated overnight at $4^{\circ} \mathrm{C}$. Membranes were then treated as described above.

\section{Muscle Creatine}

A fraction of the initial muscle biopsy $(\sim 30 \mathrm{mg})$ was used for spectrophotometric determination of total creatine (i.e., creatine phosphate + free creatine). Ground muscle was extracted in $0.25 \mathrm{~N} \mathrm{HClO}_{4}$ and neutralized with $1 \mathrm{~N} \mathrm{KOH}$. To hydrolyze creatine phosphate, $2 \mathrm{~N} \mathrm{HCl}$ was added to the supernatant, which was then heated for $15 \mathrm{~min}$ at $60^{\circ} \mathrm{C}$. The reaction was stopped on ice and the supernatant neutralized with $2 \mathrm{~N} \mathrm{NaOH}$. Total creatine was immediately determined enzymatically using a spectrophotometric method described by Guder et al. (9) (Creatinine PAP, Boerhinger Mannheim, Germany, from which the creatininase was omitted).

\section{Statistics}

Results are expressed as means \pm SEM. A repeated measures ANOVA design was used to assess the statistical significance of differences between mean values over time and between conditions. Dunnett's pairwise multiple comparison $t$-test was used as post hoc test to compare postexercise with control resting conditions. The threshold of significance was set at 0.05 . 


\section{RESULTS}

\section{Muscle Total Creatine}

Muscle total creatine concentration increased from $113 \pm$ $7 \mu \mathrm{mol} \cdot \mathrm{g}^{-1}$ dry weight to $141 \pm 10 \mu \mathrm{mol} \cdot \mathrm{g}^{-1}$ dry weight $(P<0.05)$ as a result of the creatine supplementation.

\section{IGF-I and IGF-II mRNA}

Real-time RT-PCR. Resting human skeletal muscle expressed IGF-I and IGF-II mRNA. Based on $\Delta \mathrm{Ct}$ values, IGF-I mRNA was less abundant, about one half, than IGF-II (data not shown).

IGF-I. In the placebo condition, heavy-resistance exercise increased IGF-I mRNA by $3 \mathrm{~h}$ postexercise $(24 \%, P<$ $0.05)$, which was maintained $24 \mathrm{~h}$ postexercise $(29 \%, P<$ 0.05 , Fig. $1 \mathrm{~A})$. After $5 \mathrm{~d}$ of creatine supplementation, IGF-I mRNA expression at rest was increased by $30 \%(P<0.05)$, but exercise had no further effect on this. The mRNA expression measured after exercise was similar for the creatine supplemented and the placebo conditions.

IGF-II. Under placebo, IGF-II mRNA level was increased by $48 \%$ at $3 \mathrm{~h}$ postexercise $(P<0.05)$, and returned to values similar to rest $24 \mathrm{~h}$ postexercise (Fig. 1B). Creatine supplementation upregulated the expression of IGF-II
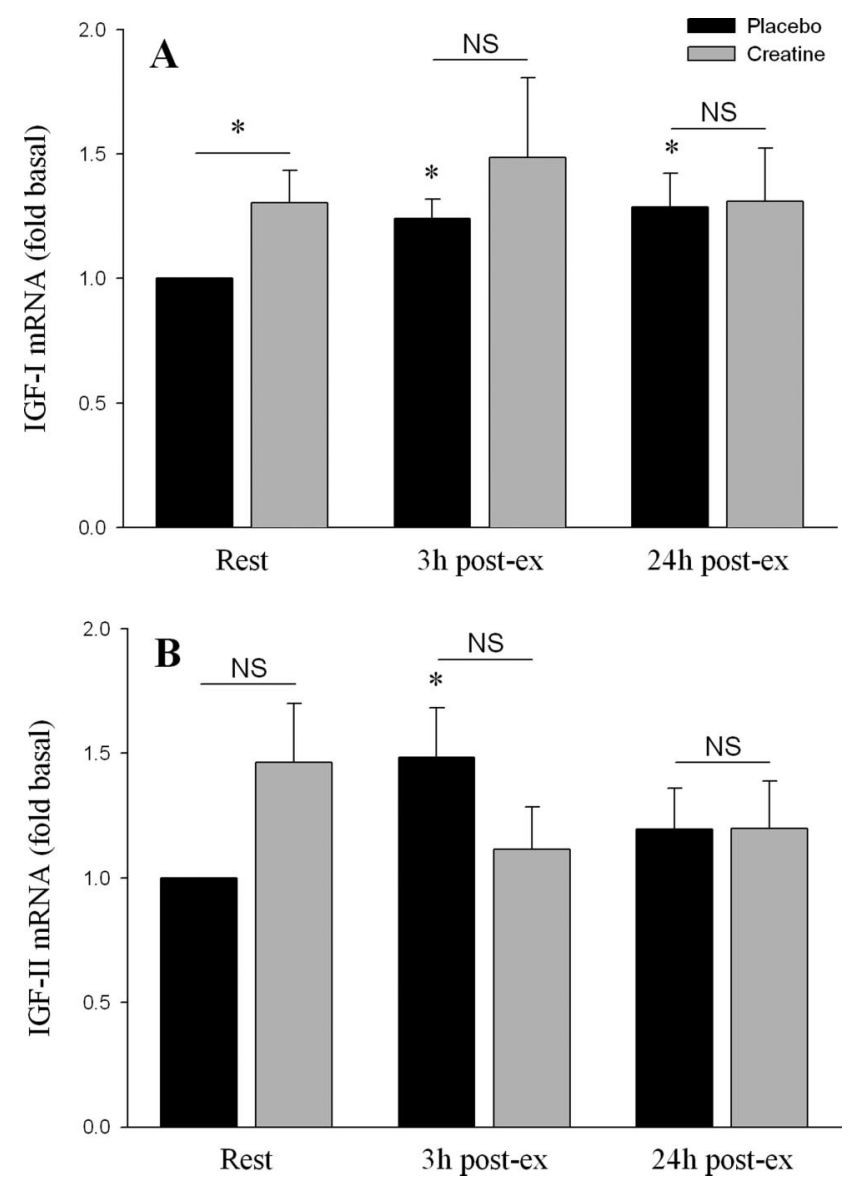

FIGURE 1-mRNA level of IGF-I (A) and IGF-II (B) in placebo and creatine conditions at rest and after exercise. Symbols above histograms depict significant differences with rest under the same treatment; $* P<0.05$.
mRNA at rest (46\%), although the statistical threshold was not reached $(P=0.054)$ due to the variability induced by one of the six subjects. In creatine-supplemented subjects, IGF-II mRNA expression dropped $20 \% 3 \mathrm{~h}$ and $24 \mathrm{~h}$ after exercise, but these values were not statistically different from rest condition.

\section{Phosphorylation state of $\mathrm{p} 70^{\mathrm{s} 6 \mathrm{k}}$ and 4E-BP1}

p70 ${ }^{\mathbf{s k}}$. Three hours postexercise plus feeding, the phosphorylation state of $\mathrm{p} 70^{\mathrm{s} 6 \mathrm{k}}$ increased by about $400 \%$ both in the placebo $(P<0.001)$ and creatine conditions $(P<0.05$, Fig. 2A). The phosphorylation state of $\mathrm{p} 70^{\mathrm{s} 6 \mathrm{k}}$ returned to basal values $24 \mathrm{~h}$ postexercise. Creatine had no additional effect on the phosphorylation state of $\mathrm{p} 70^{\mathrm{s} 6 \mathrm{k}}$.

4E-BP1. In the placebo condition, the fraction of 4EBP1 in the gamma form was approximately doubled $3 \mathrm{~h}$ postexercise $(P<0.05$, Fig. 2B). It also increased 1.5 -fold in the creatine condition, but the significance threshold was not reached $(P=0.06)$. Twenty-four hours postexercise, the

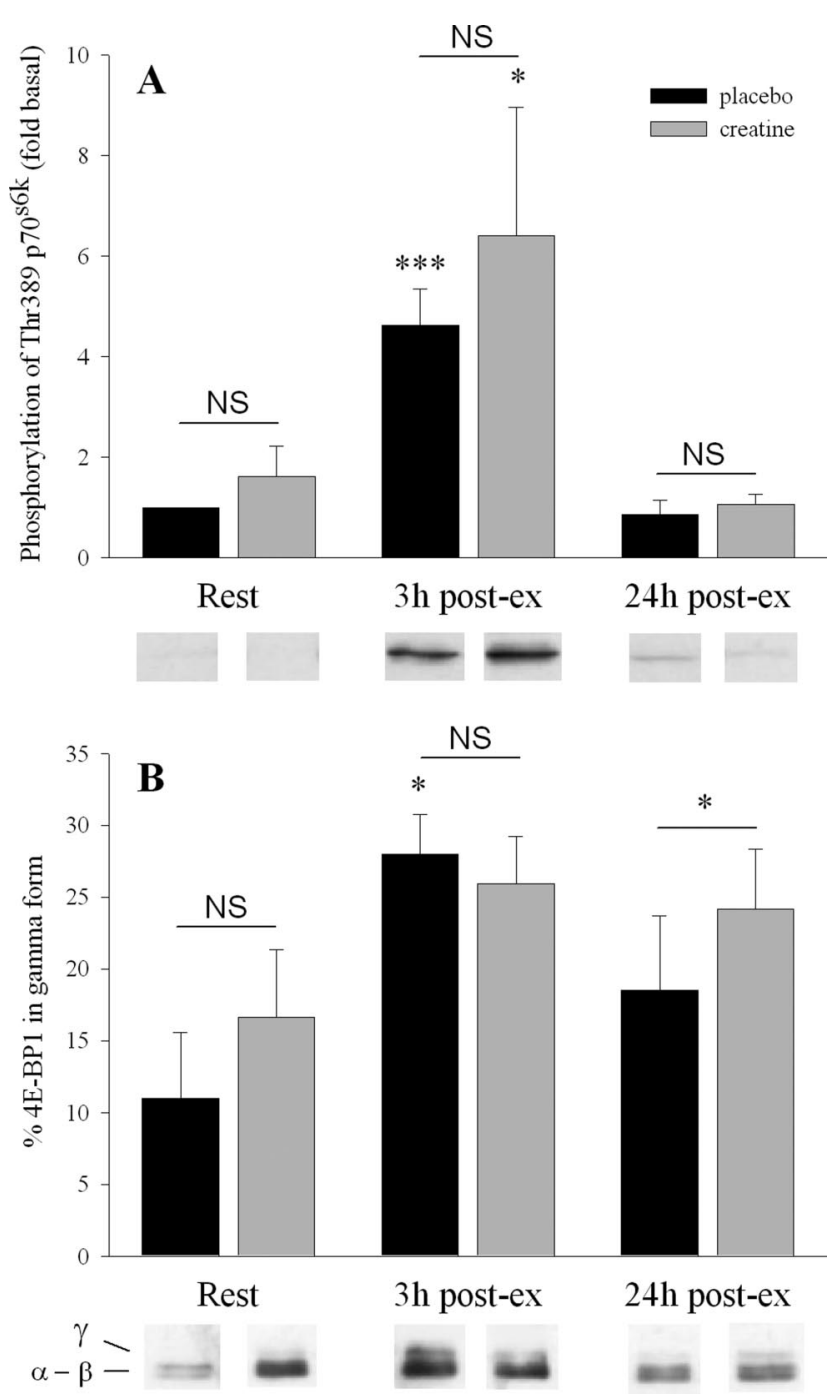

FIGURE 2-Changes in the phosphorylation state of p70 ${ }^{\mathrm{s} 6 \mathrm{k}}$ (A) and 4E-BP1 (B) in placebo and creatine conditions at rest and after exercise. Symbols above histograms depict significant differences with rest under the same treatment; $* P<0.05 ; * * * P<0.001$. 
phosphorylation state of 4E-BP1 displayed a slight decrease toward basal values. It was not affected by creatine at rest and at $3 \mathrm{~h}$ postexercise, but remained more elevated, and thus different from placebo, at $24 \mathrm{~h}$ postexercise $(P<0.05)$.

\section{DISCUSSION}

Recently, we observed that creatine added to the culture medium of myogenic cells $\left(\mathrm{C}_{2} \mathrm{C}_{12}\right)$ improved cell differentiation and increased expression of the IGF-I mRNA (16). In the present study, we hypothesized that expression of IGF would also be increased in human skeletal muscle after $5 \mathrm{~d}$ of creatine supplementation. Indeed, the amount of IGF-I was higher in resting muscle after creatine intake, and IGF-II mRNA showed an increasing trend (Fig. 1). Although the increases in IGF mRNA were only $30-40 \%$, they may help to enhance the anabolic milieu in skeletal muscle, which could explain the increase in muscle mass reported after creatine supplementation (see below) $(3,8)$.

Exercise did not induce a further change in IGF-I and IGF-II mRNA when the subjects were supplemented with creatine (Fig. 1, A and B). This indicates that both exercise and creatine increase the expression of IGF, but that these effects are not cumulative.

Even though the design of the present study does not enable us to distinguish the confounding effects of exercise and feeding at $3 \mathrm{~h}$ postexercise, a $20 \%$ increase in IGF mRNA was observed $3 \mathrm{~h}$ and $24 \mathrm{~h}$ after a session of resistance exercise. Bamman et al. (4) already reported a $62 \%$ increase in IGF-I mRNA after a bout of eccentric exercises at $110 \%$ of the $1-\mathrm{RM}$ and a trend to upregulation after concentric exercises at $85 \%$ of the 1-RM. The results of the present study $(+24 \%)$ compare well with the data reported by those authors because the leg-press exercise was performed against a load equal to $70 \%$ of the 1-RM. On the other hand, the effect of creatine in the resting condition reached similar range of increase $(+30 \%)$. The upregulation of IGF-I mRNA could be a mechanism by which exercise and creatine exert their effect on muscle hypertrophy.

Whereas evidence linking muscle activity and local IGF-I and IGF-II availability is growing, the mechanism by which muscle overload modulates IGF-I and IGF-II expression is unclear. In mammals, the IGF-I gene consists of six exons with several regulating promoters (10). In skeletal muscle, IGF-I transcription appears to be mostly regulated by the exon 1 promoter, which is activated by MyoD and the calcium signaling molecule calcineurin (17).

Once bound to their common receptor, IGF can stimulate several signaling pathways, among others the PI3K-Akt/ PKB-mTOR pathway (7), which plays an important role in the regulation of muscle hypertrophy. The PI3K-Akt/PKBmTOR pathway and its downstream targets $\mathrm{p} 70^{\mathrm{s} 6 \mathrm{k}}$ and $4 \mathrm{E}-$ BP1 can also respond to other signals such as exercise and feeding. In rats, the activation of this pathway after exercise

\section{REFERENCES}

1. Allen, R. E., and L. K. Boxhorn. Regulation of skeletal muscle satellite cell proliferation and differentiation by transforming is rapid and large, more than double in a few minutes (5). Thus, in contrast to the delayed-response regulation by IGF, exercise and feeding induce an early response at the level of $\mathrm{p} 70^{\mathrm{s} 6 \mathrm{k}}$ and 4E-BP1, comparable to an on/off switch (22), as confirmed by the present results. Phosphorylation of $\mathrm{p} 70^{\mathrm{s} 6 \mathrm{k}}$ was measured using an antibody recognizing phosphorylated Thr 389, which corresponds to the highest level of phosphorylation of p $70^{\mathrm{s} 6 \mathrm{k}}$ and its highest activity (28). The phosphorylation state of $\mathrm{p} 70^{\mathrm{s} 6 \mathrm{k}}$ increased fourfold $3 \mathrm{~h}$ postexercise (Fig. 2A) in accordance with previous studies on rats (2). Six hours after high-resistance lengthening contractions, the activity of $\mathrm{p} 70^{\mathrm{s} 6 \mathrm{k}}$ in rats was tripled, and the phosphorylation of $\mathrm{p} 70^{\mathrm{s} 6 \mathrm{k}}$ correlated with increased skeletal muscle mass after $6 \mathrm{wk}$ of training (2). Creatine ingestion did not potentiate the phosphorylation of $\mathrm{p} 70^{\mathrm{s} 6 \mathrm{k}}$ in the present study.

The effect of exercise on 4E-BP1 has been less extensively investigated. In our study, exercise doubled the gamma form of 4E-BP1, which is the most phosphorylated form of the protein (18) (Fig. 2B). No supplementary effect of creatine was found $3 \mathrm{~h}$ postexercise. However, the gamma form of 4E-BP1 remained more elevated than in the placebo condition $24 \mathrm{~h}$ postexercise. The activation of $4 \mathrm{E}-$ BP1 by phosphorylation results in its release from eIF4E and allows the latter to participate in the initiation of protein synthesis by enabling the formation of the eIF4F complex.

The dissimilar effects of creatine on 4E-BP1 and $\mathrm{p} 70^{\mathrm{s} 6 \mathrm{k}}$ are surprising because both proteins are downstream targets of the same pathway. Nevertheless, other involved factors, like the protein phosphatase $2 \mathrm{~A}$ and/or a crosstalk between the MEK/MAPK pathway and $\mathrm{p} 70^{\mathrm{s} 6 \mathrm{k}}$, cannot be excluded and may explain the difference. Creatine could have a more direct effect on 4E-BP1 and maybe not on $\mathrm{p} 70^{\mathrm{s} 6 \mathrm{k}}$. Clearly, further research is warranted to clarify these issues.

In summary, creatine supplementation had no potentiating effect on the activation of $\mathrm{p} 70^{\mathrm{s} 6 \mathrm{k}}$ and $4 \mathrm{E}-\mathrm{BP} 13 \mathrm{~h}$ after acute exercise. As already pointed out, the increase in the phosphorylation state of $\mathrm{p} 70^{\mathrm{s} 6 \mathrm{k}}$ and 4E-BP1 after $3 \mathrm{~h}$ was not due to exercise alone but was induced by both acute exercise (5) and feeding (13). These observations are in accordance with our previous finding that in comparable conditions, creatine did not enhance protein synthesis within a short time frame $(14,15)$. Creatine increased the expression of IGF-I only at rest with no additional effect of exercise. The phosphorylation state of 4E-BP1 was also found to be more elevated $24 \mathrm{~h}$ postexercise. Our results indicate that creatine supplementation could act to stimulate muscle growth, but not by a rapidly responding control system as observed after exercise plus feeding, but rather by a late-response enhancement of the anabolic status of the cell involving IGF.

This work is granted by the "Fonds de la Recherche Scientifique Médicale" (3.4574.03), Belgium. 
2. BAAR, K., and K. EsSER. Phosphorylation of p70(S6k) correlates with increased skeletal muscle mass following resistance exercise. Am. J. Physiol. 276:C120-C127, 1999.

3. Balsom, P. D., S. D. Harridge, K. Soderlund, B. Suodin, and B. Еквцом. Creatine supplementation per se does not enhance endurance exercise performance. Acta Physiol. Scand. 149:521-523, 1993.

4. Bamman, M. M., J. R. Shipp, J. Jiang, et al. Mechanical load increases muscle IGF-I and androgen receptor mRNA concentrations in humans. Am. J. Physiol. Endocrinol. Metab. 280:E383E390, 2001.

5. Bolster, D. R., N. Kubica, S. J. Crozier, et al. Immediate response of mammalian target of rapamycin (mTOR)-mediated signalling following acute resistance exercise in rat skeletal muscle. J. Physiol. 553:213-220, 2003.

6. Brunn, G. J., C. C. Hudson, A. Sekulic, et al. Phosphorylation of the translational repressor PHAS-I by the mammalian target of rapamycin. Science 277:99-101, 1997.

7. Coolican, S. A., D. S. Samuel, D. Z. Ewton, F. J. McWade, and J. R. FLORINI. The mitogenic and myogenic actions of insulin-like growth factors utilize distinct signaling pathways. J. Biol. Chem. 272:6653-6662, 1997.

8. Francaux, M., and J. R. Poortmans. Effects of training and creatine supplement on muscle strength and body mass. Eur. J. Appl. Physiol. Occup. Physiol. 80:165-168, 1999.

9. Guder, W. G., G. E. Hoffmann, A. Hubbuch, W. A. Poppe, J. SiEdel, and C. P. Price. Multicentre evaluation of an enzymatic method for creatinine determination using a sensitive colour reagent. J. Clin. Chem. Clin. Biochem. 24:889-902, 1986.

10. Hall, L. J., Y. Kалімото, D. Bichell, et al. Functional analysis of the rat insulin-like growth factor I gene and identification of an IGF-I gene promoter. DNA Cell. Biol. 11:301-313, 1992.

11. Jefferies, H. B., S. Fumagalli, P. B. Dennis, C. Reinhard, R. B. Pearson, and G. Thomas. Rapamycin suppresses 5'TOP mRNA translation through inhibition of p70s6k. EMBO J. 16:3693-3704, 1997.

12. Kaliman, P., J. Canicio, X. Testar, M. Palacin, and A. ZorZano. Insulin-like growth factor-II, phosphatidylinositol 3-kinase, nuclear factor-kappaB and inducible nitric-oxide synthase define a common myogenic signaling pathway. J. Biol. Chem. 274:1743717444, 1999.

13. Liu, Z., L. A. Jahn, W. Long, D. A. Fryburg, L. Wei, and E. J. BARRETT. Branched chain amino acids activate messenger ribonucleic acid translation regulatory proteins in human skeletal muscle, and glucocorticoids blunt this action. J. Clin. Endocrinol. Metab. 86:2136-2143, 2001.

14. Louis, M., J. R. Poortmans, M. Francaux, et al. No effect of creatine supplementation on human myofibrillar and sarcoplasmic protein synthesis after resistance exercise. Am. J. Physiol. Endocrinol. Metab. 285:E1089-E1094, 2003.

15. Louis, M., J. R. Poortmans, M. Francaux, et al. Creatine supplementation has no effect on human muscle protein turnover at rest in the postabsorptive or fed states. Am. J. Physiol. Endocrinol. Metab. 284:E764-E770, 2003.
16. Louis, M., R. Van Beneden, M. Dehoux, J. P. Thissen, and M. FrancauX. Creatine increases IGF-I and myogenic regulatory factor mRNA in C(2)C(12) cells. FEBS Lett. 557:243-247, 2004.

17. McCall, G. E., D. L. Allen, F. Haddad, and K. M. Baldwin. Transcriptional regulation of IGF-I expression in skeletal muscle. Am. J. Physiol. Cell. Physiol. 285:C831-C839, 2003.

18. Mothe-Satney, I., G. J. Brunn, L. P. McMahon, C. T. Capaldo, R. T. Abraham, and J. C. Lawrence., JR. Mammalian target of rapamycin-dependent phosphorylation of PHAS-I in four (S/T)P sites detected by phospho-specific antibodies. J. Biol. Chem. 275: 33836-33843, 2000.

19. Murphy, R. M., K. K. Watt, D. Cameron-Smith, C. J. Gibbons, and R. J. SNOw. Effects of creatine supplementation on housekeeping genes in human skeletal muscle using real-time RT-PCR. Physiol. Genomics 12:163-174, 2003.

20. Proud, C. G. p70 S6 kinase: an enigma with variations. Trends Biochem. Sci. 21:181-185, 1996.

21. Rennie, M. J. Control of human muscle protein synthesis as a result of contractile activity and amino acid availability: implications for protein requirements. Int. J. Sport Nutr. Exerc. Metab. 11:S170-S176, 2001.

22. Rennie, M. J., and H. Wackerhage. Connecting the dots for mechanochemical transduction in muscle. J. Physiol. 553:1, 2003.

23. SaKamoto, K., and L. J. Goodyear. Invited review: intracellular signaling in contracting skeletal muscle. J. Appl. Physiol. 93:369383, 2002.

24. Sartorelli, V., and M. Fulco. Molecular and cellular determinants of skeletal muscle atrophy and hypertrophy. Sci. STKE re11, 2004.

25. Sneddon, A. A., M. I. Delday, J. Steven, and C. A. Maltin. Elevated IGF-II mRNA and phosphorylation of 4E-BP1 and p70(S6k) in muscle showing clenbuterol-induced anabolism. Am. J. Physiol. Endocrinol. Metab. 281:E676-E682, 2001.

26. Tarnopolsky, M. A., G. Parise, N. J. Yardley, C. S. Ballantyne, S. Olatinji, and S. M. Phillips. Creatine-dextrose and proteindextrose induce similar strength gains during training. Med. Sci. Sports Exerc. 33:2044-2052, 2001.

27. Volek, J. S., N. D. Duncan, S. A. Mazzetti, et al. Performance and muscle fiber adaptations to creatine supplementation and heavy resistance training. Med. Sci. Sports Exerc. 31:1147-1156, 1999.

28. Weng, Q. P., M. Kozlowski, C. Belham, A. Zhang, M. J. Comb, and J. Avruch. Regulation of the p70 S6 kinase by phosphorylation in vivo. Analysis using site-specific anti-phosphopeptide antibodies. J. Biol. Chem. 273:16621-16629, 1998.

29. Willoughby, D. S., and J. Rosene. Effects of oral creatine and resistance training on myosin heavy chain expression. Med. Sci. Sports Exerc. 33:1674-1681, 2001.

30. Xu, G., C. A. Marshall, T. A. Lin, et al. Insulin mediates glucose-stimulated phosphorylation of PHAS-I by pancreatic beta cells: an insulin-receptor mechanism for autoregulation of protein synthesis by translation. J. Biol. Chem. 273:4485-4491, 1998. 